\title{
C. STUART HOUSTON OF SASKATOON HONOURED
}

MARY D. GILLILAND, 902 University Drive, Saskatoon, Saskatchewan, S7N and

ARDYTHE MCMASTER, 306 Brock Street, Winnipeg, Manitoba. R3N OY9

In the decades since he began helping Isabel Priestly publish the fledgling Blue Jay, Dr. C. Stuart Houston has received much recognition for his contributions to North American ornithology. His honours include the Canadian Wildlife Federation's Roland Michener Conservation Award and the Canadian $\mathrm{Na}$ ture Federation's Douglas H. Pimlott Award, the latter awarded jointly to Stuart and Mary Houston "for outstanding and enduring achievement in wild life conservation." When the Saskatchewan Natural History Society created a new class of membership, "Fellow," to mark long service and contribution to its work, Stuart and Mary Houston were among the first named.

In 1989, Stuart has been three times singled out for special recognition. He was elected a Fellow of the American Ornithologists' Union - 14th from Canada and the only amateur to be so recognised. The Society of Canadian Ornithologists named him recipient of its Doris Huestis Speirs Award, citing his many years of birdbanding and numerous papers and books - particularly those on naturalists of the Franklin expeditions, which have achieved international recognition and citations of excellence.

This year as well, the Manitoba Naturalists' Society presented to Stuart its prestigious Ralph D. Bird Award, for a lifetime of work for wild life and conservation and for achievements reaching far beyond the Prairies.

Following are excerpts from the offi- cial presentation, written and delii by Ardythe McMaster, SNHS Reg Director from Manitoba.

"On the windswept grasslands Canadian prairies can be found the steps of a rare prairie species, tine Prairie Naturalist... In the paths of $t$ giants can be found impressive evid: of their talents for keen and careft servation, their abilities to recruit, 0 ise and coordinate others to assist t and their energies to record and $\mathrm{pu}$ their findings. In their giant foot: other naturalists may follow, their ways set by those who have gor before and shown the way.

"Once upon a time, as all good si begin, when one Isabel Pri moved...to Yorkton, she encouraged...to start a naturalists there... She began to write a small tin issued every four months.. named her bulletin Blue Jay, afte noisy, lively, gossipy Thornton $W$. gess character, Sammy Jay, who about the meadows and wood 'spreading the news.' Stuart Ho was just a kid growing up in Yorkt that time. He was its first seci treasurer; he mimeographed the $c$ for circulation, and he and his bu helped Isabel Priestly by crayonin colour covers of her infant public What a start for these two $y$ fledglings! Blue Jay, 'a journal of $n$ history and conservation for Saske wan and adjacent regions' has gro become one of the outstanding $n$ history journals on the continent, 
lart Houston, a regular Blue Jay conutor over the years, has grown to come this prairie giant we hour...known (like Blue Jay) across continent...

"tt would be true...to say that he works hatural history in his spare time, but it uld be...equally accurate to say that oreathes in his spare time! In broadterms he could be described as an ithologist with a particular interest in tors and colonial nesters, but this cription would be too narrow, even ugh we know that he has banded ut 5000 Great Horned Owls, and that Houstons' total birds banded is just it of 100,000 ! He is keenly interested he changing patterns of bird distribureflecting as they do the changing of the prairies. He has researched written about many early prairie uralists and their work. His work les our interest and heightens our reciation for the rich treasure left by se pioneer men and women... In all art Houston has published over 250 ks on ornithological and natural histopics!

But how wrong...to think of [him] eted in his study typing out articles... ure him arriving home from the airfrom a business meeting early on a day morning, gathering lunches, Is, shovels, and a herd of young is one third his age to spend the day ing in nest boxes for Burrowing Owls puple of hundred miles away. Or ling nest platforms for Ferruginous ks or Ospreys. Or climbing up tall $s$, or rappelling down steep cliffs, to raptor nestlings. Think also of [him] e control centre for a huge network cople who work with and for him, a er who encourages and challenges, inspires by example...

Mary Houston..needs..mention here, As cook, clerk, stenographer, social etary, deputy, research assistant,

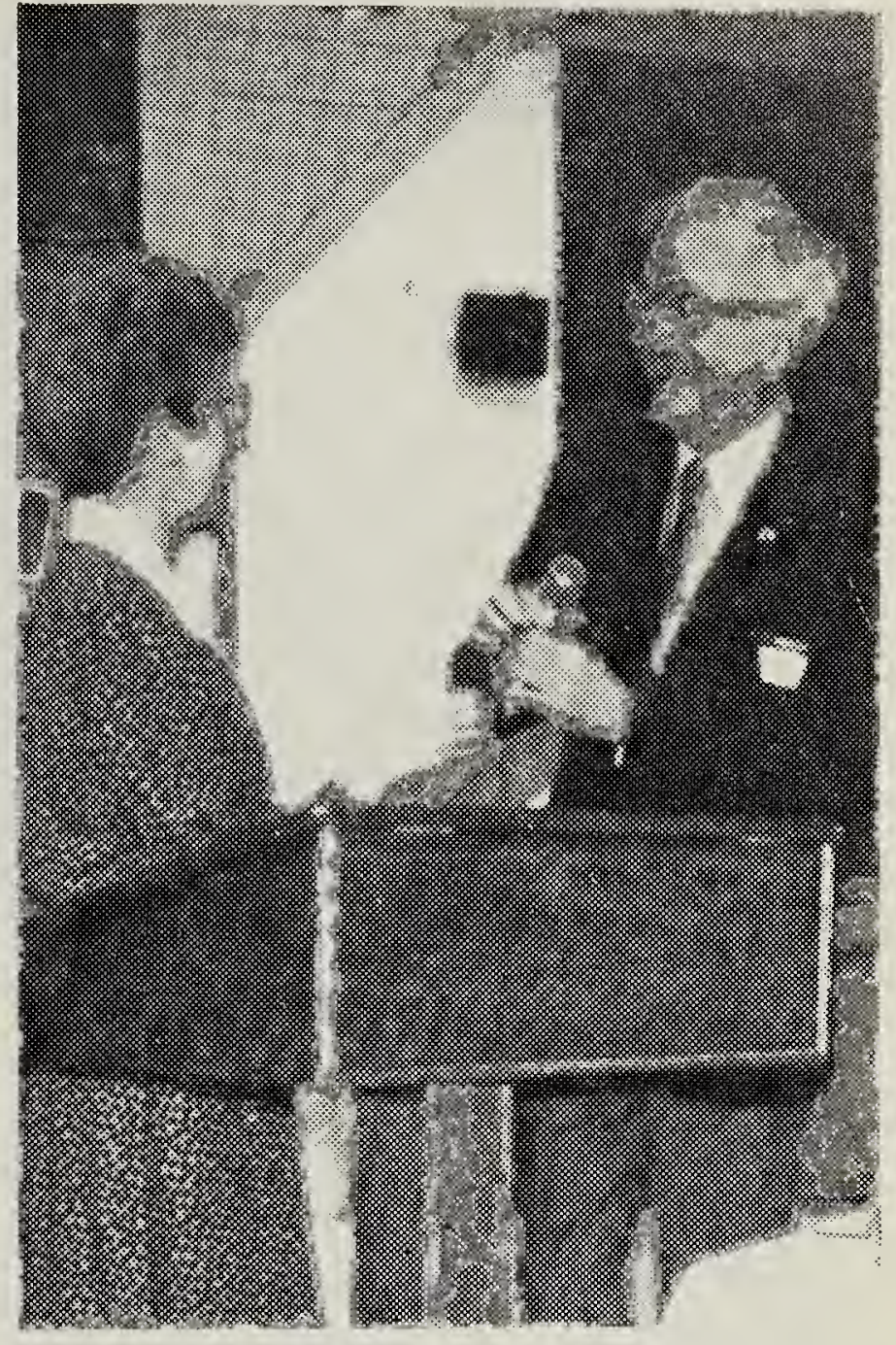

C. Stuart Houston receives Ralph D. Bird Award

data compiler, gracious hostess, companion and friend, she is the outstanding example of the woman behind the successful man, and Stuart himself would be the first to agree. A naturalist in her own right, Mary runs... bluebird nestlines, bands passerines in her backyard traps, and annually coordinates the Saskatchewan Christmas bird and mammal counts...

"As our Society honours Stuart Houston and his work...we recognise that both we and the award are honoured by the stature of the recipient... [who reminds us] of our heritage, our common goals, our potential, our challenge...[whose] footsteps [invite] us to follow, to get in on the excitement, to join in the fun. There is a giant among us: Stuart Houston." 